\title{
NOTES
}

\section{DISCRIMINATORY FREIGHT RATES: IMPLICATIONS OF THE INTERSTATE COMMERCE COMMISSION'S REGULATORY POWERS}

When the Class Rate Investigation was undertaken in 1939 , it was clearly recognized that the Interstate Commerce Commission was meeting its most severe test. It was faced with the task of analyzing and extirpating deep-seated inter-territorial rate discriminations which it had previously fostered. ${ }^{x}$ The entire problem was set in an atmosphere of great political agitation and pressures." The Commission's decision ${ }^{3}$ handed down in 1945 represented a great achievement from the standpoint of achieving a more balanced economy geographically and removing barriers to the economic location of industry and movement of commodities. It was hailed as the most important and far-reaching economic decision in American history. But those who exult in the contemplation of the economic gains likely to ensue from the decision are apt to overlook the legal and political implications stemming from the Commission's decision and its subsequent approval by the Supreme Court. 4 In a period in which the ICC's sole jurisdiction over the railroad affairs of the nation is being seriously challenged, 5 these decisions throw much light on the workings of the regulatory

$\therefore$ The extent to which the freight rate structure as a whole discriminated against the South and the West is shown in TVA, Regionalized Freight Rates: Barrier to National Productiveness, H. R. Doc. 137, 78th Cong. Ist Sess. (1943); Board of Investigation and Research, Transportation Act of 1940, Summary Report on Interterritorial Freight Rates (r943). The Class Rate Investigation was concerned only with the class rate structure, which evolved through a series of decisions by the ICC. First class rates, to which all other classes are tied by percentile relation, were 39 per cent higher in Southern Territory than in Official Territory, and Western rates were from 28 to 84 per cent higher than Official rates, according to the studies cited above. See Potter, The Historical Development of Eastern-Southern Freight Rate Relationships, I2 Law \& Contemp. Prob. 416 (1947).

${ }^{2}$ See dissent of Commissioner Eastman in Alabama v. New York Central R.R. Co., 235 I.C.C. 255,333 (I939). For a discussion of the political influences exerted on the Commission see the editorial in N. Y. Times, p. 18, col. 3 (May 2I, I945). No fewer than six bills were before Congress in I939 calling for modification of the Commission's regulatory powers to force removal of the discriminations. Hearings before Subcommittee of the Senate Committee on Interstate Commerce on Freight Rate Discriminations, 76th Cong. Ist Sess. (1939). The suggestion was also made that federal district courts be given broad powers to act in rate disputes. N. Y. Times $\$ 6$, p. 5, col. 3 (March $x_{9}$, I939).

3 Class Rate Investigation, 1939, 262 I.C.C. 477 (1945).

$4 \mathrm{New}$ York v. United States, 67 S. Ct. I207 (1947).

5 See Wiprud, Justice in Transportation (I945); Dumbauld, Rate-Fixing Conspiracies in Regulated Industries, 95 U. of Pa. L. Rev. 643 (I947). For a defense of the ICC and the regulatory process see the answer to Wiprud in Drayton, Transportation under Two Masters (1946). 
process in handling contemporary problems. The issues opened up by these decisions will add much fuel to the controversies now raging as to the proper relationship between the State and monopoly, competition and control, and free . enterprise and nationalization in the field of American transportation.

The phrase "discrimination" must be used in a neutral sense because the very nature of the freight rate structure necessarily involves discrimination without motive to injure the commodity, shipper, or region discriminated against. The division of the nation into autonomous rate-making territories, ${ }^{6}$ each of them arbitrarily classifying articles of traffic into classes, fixing percentile relationships between and setting rates on the classes, creates the first source of inherent discrimination. ${ }^{7}$ An equally important discriminatory factor is the character of the rate structure. ${ }^{8}$ It has long been observed that the railroad rate structure departs from traditional notions of economic theory in that there is little relation between the cost of producing the service and the price charged shippers for the service. A very large proportion of the total costs of the railroads are the fixed costs, which remain substantially the same no matter how much traffic is handled. The carriers find that if they charge rates which cover their total costs of producing the particular service, many shippers will not utilize their services, and a large part of their capacity will be unused. Consequently, the railroads find it to their advantage to utilize each unit of their capacity, as long as the use of that unit brings a return covering the out-ofpocket costs plus a small additional amount to be applied to the fixed costs. Any business enterprise will continue to operate as long as the out-of-pocket expenses are met, even if the fixed costs cannot be met, but it is only a monopoly which can continue operating under these circumstances indefinitely. Thus, railroad rates, instead of approximating the economists' ideal of being equated with costs in order to achieve the proper allocation of resources throughout the economy, are based upon the principle of "charging what the traffic will bear," or more euphemistically, on "value of service" or "demand." The Interstate Commerce Commission has repeatedly recognized this manner of constructing

${ }^{6}$ There are three main classification territories: Official or Eastern, Southern, and Western. The Class Rate Investigation was concerned with these three territories with the exception of the subdivision of Western Classification Territory known as Mountain Pacific Territory, which comprises that area west of the Rocky Mountains.

7 There was no uniformity in the articles comprising each class, the nomenclature of the classes, the percentile relationships between the class rates, or the class rates themselves for each class among the three major territories. See Heath, The Rate Structure, I2 Law \& Contemp. Prob. 405 (1947); Locklin, Economics of Transportation I68-75 (I938); Alldredge, Rate-Making for Common Carriers $\$ \$ 48-52$ (I929).

${ }^{8}$ See Locklin, The Literature on Railway Rate Theory, 47 Q. J. Econ. I67 (I933) for a summary of economists' analyses seeking to explain the divergence of railway rates from conventional economic theory.

9 Bigham, Transportation I08-II (I946); Locklin, Economics of Transportation 140-66 (1938). See also Locklin, Can Existing Regional Differences in Class-Rate Levels Be Justified, I2 Law \& Contemp. Prob. 495, 502-5 (r947). 
freight rates by acknowledging value of service considerations as one of the major factors to be considered in rate-making. ${ }^{.0}$

The Commission's test of the reasonableness of a rate has always been whether the rate has been established in conformity with accepted transportation criteria, chief among which are cost of service and value of service. ${ }^{\text {II }}$ The Commission is also empowered to enforce the prohibitions against undue discrimination..$^{12}$ It has been realized that rates which are reasonable per se may, in relation to other rates, be discriminatory. ${ }^{\mathrm{I}} 3$ Nevertheless, the test of undue discrimination has been expressed in terms similar to those used to describe the test of unreasonableness. ${ }^{14} \mathrm{~A}$ discrimination is undue or unlawful only if it is not justified by transportation criteria. Such a test would seem to imply that if both rates were located within the "zone of reasonableness," and the discrimination could not be removed by adjusting the rates within this zone, the discrimination is not unlawful. This test is entirely unrealistic in failing to take into account the fact that the railroads, in maximizing their net revenue, are in a position to do so by adopting any one of a large number of possible rate combinations. By deciding that the rate burden will be distributed in one possible manner instead of another, the railroads are able to determine the competitive relationships of commodities and geographical territories. ${ }^{15}$ In the Class Rate Investigation, the Commission seems to take a new view of the problem of discrimination, and its language indicates that henceforth the test of discrimination will be whether the injurious prejudices and preferences established by the railroad rate structure may be eliminated by some other distribution of the rate burden. Under this view railroads are commanded to distribute the rate burden in such a manner as to avoid creating discrimination, preference, and prejudice, and the Commission's duty has become that of insuring that the public interest, as well as the

${ }^{20} \mathrm{New}$ Automobiles in Interstate Commerce, 259 I.C.C. 475 (1945); Frohman Chemical Co. v. Baltimore \& Ohio Ry., II I.C.C. 322 (1926); 3 B Sharfman, The Interstate Commerce Commission $425-63$ (I936). Value of service has often been regarded as the maximum point of a reasonable rate. Bituminous Coal to C.F.A. Territory, 46 I.C.C. 66 , I 2 (Igr7).

${ }_{3}$ B Sharfman, op. cit. supra note 10 , at $425-63$.

12 Interstate Commerce Act $\$ 3$ (I), 24 Stat. 380 (r887), as amended, 49 U.S.C.A. $§ 3$ (Supp., I946).

${ }_{23}$ United States v. Illinois Central R.R. Co., ${ }_{263}$ U.S. $5^{15}$ (I924); Interstate Commerce Commission v. Baltimore \& Ohio Ry. Co., $x_{45}$ U.S. 263 (r892).

$x_{4}$ "To bring a difference in rates within the prohibition of $\S 3$ it must be shown that the discrimination practiced is unjust when measured by the transportation standard. In other words, the difference in rates cannot be held illegal unless it is shown that it is not justified by the cost of the respective services, by their values, or by other transportation conditions." United States v. Illinois Central R.R. Co., 263 U.S. 515 , 524 (I924); 3B Sharfman, op. cit. supra note Io, at 536 .

${ }_{75}$ The railroads have the power to induce production and traffic which is wholly uneconomic judged from the national economic viewpoint. By means of "missionary rates" they frequently develop new industries in new areas in order to get new business. Much of the turmoil in the bituminous coal industry is a direct result of such tactics used to open up the southern coal fields. See Mansfield, The Lake Cargo Coal Controversy (1932). 
private interest of the carriers, is taken into consideration in the distribution of the rate burden. ${ }^{16}$ This represents a marked turnabout in the philosophy of rate regulation. Heretofore a relationship was unjust when it could not be justified in terms of transportation necessity; now a relationship is unjust when it is found that freight rates hinder one economic entity's competition against another, and an adjustment of the rate burden which will remove the discrimination is possible of attainment. Whereas commercial factors previously were not a consideration in the reasonableness of a relation between two rates, ${ }^{17}$ they now become the major test of discrimination.

In establishing this new view of discrimination, the Commission relied heavily upon the Transportation Act of I940..$^{\text {I8 }}$ By this Act, Section 3(I) of the Interstate Commerce Act ${ }^{\mathrm{Ig}}$ was amended to bring regions, districts, and territories specifically under the prohibitions against unreasonable discrimination. Another component of the Act was the Ramspeck Resolution, ${ }^{20}$ which directed the Commission to investigate inter-territorial rates and to remove any unlawfulness found to exist. While the Commission apparently did not interpret the legislation as a mandate to equalize rates per given distance on all commodities, it did feel that the amendments to Section 3(I) enlarged the scope of its powers. Although the intent of Congress undoubtedly was to achieve a greater equalization of freight rates, ${ }^{2 x}$ the new legislation left intact and unchanged the key concepts of "undue," "unreasonable," and "unjust." There is no evidence that Congress intended to work such a transmutation of these concepts, and its constitutional power to do so is doubtful.22

16 "By the amendment to the substantive anti-discrimination provisions of Section 3 (I) all discriminations .... as between regions, districts, or territories .... were brought within the purview of the act. .... Such discriminations.... . which result from differences in the methods of distributing the rate burden in the several rate-making territories, or from any other cause, if not justified upon proper consideration of recognized elements of rate making applied in the light of the amended law are unlawful. . ..." Class Rate Investigation, I939, 262 I.C.C. 447,692 (r945) (italics added).

${ }_{17}$ Mansfield, op. cit. supra note $5_{5}$ at $234-56$; 3 B Sharfman, op. cit. supra note Io, at $762-$ 63.

${ }^{{ }^{8}} 54$ Stat. 899 (I940), 49 U.S.C.A. (Supp., I940). $\quad{ }^{29} 4 \mathrm{I}$ Stat. 479 (I920).

${ }^{20} 54$ Stat. 899, 902 (I940), 49 U.S.C.A. $\$ 3$ note (Supp., I940).

"Comparison of the "anti-discrimination"legislation of r940 with the Hoch-Smith Resolution, Pub. Res. 46, 68th Cong. Ist Sess. (Jan. 30, 1925), is instructive. This resolution ordered the Commission to consider commercial conditions in rate-making. The implication of intent to equalize rates is much more obvious than in the 1940 legislation. But Congress apparently regarded it merely as a "sop" thrown to the agricultural interests. 65 Cong. Rec. rro23-24 (I924); Hearings on the Confirmation of John J. Esch, Senate Committee on Interstate Commerce, 7oth Cong. rst Sess. (1928). The Supreme Court regarded the Resolution as merely the hopeful characterization of an object deemed desirable, and held that the criteria of ratemaking were unchanged by the Resolution. Ann Arbor R.R. Co. v. United States, 28I U.S. 658 (I930).

22 The Ann Arbor case did not pass on the power of Congress to enact legislation infusing commercial considerations into the rate-making process, but there are strong indications that it seriously questioned this power. Ann Arbor R.R. Co. v. United States, 28 I U.S. 658, 669 (I930). 
This new view greatly expands the Commission's power to deal with many types of discrimination, and the new philosophy represents a significant step forward in that the sovereignty of private monopoly in determining competitive relationships within a wide area of the economy has been brought under the control of an agency of the government.23

Under the new view of unjust discrimination, crucial problems arise where the matter of its removal is considered. Undue preference, prejudice, and discrimination may be removed by the Commission by an order under Section 3, which merely orders the carrier itself to remove the discrimination, or by an order under Section I5(I), ${ }^{34}$ which allows the Commission to set maximum or minimum rates or maximum and minimum rates. In the Class Rate Investigation, the Commission found that the discrepancy between Official Territory and Southern and Western Territory class rates could not be justified on the basis of transportation factors traditionally regarded as the standards for rate fixing. ${ }^{25}$ The Supreme Court upheld the Commission because there was substantial evidence supporting these findings, and the Court felt that the determination of these matters was primarily a matter for the Commission. ${ }^{26}$ To remove the discrimination the Commission ordered a uniform classification of freight to be instituted by the carriers. A schedule of uniform class rates, which was approximately $x 5$ per cent above existing Official Territory class rates, was to become effective at the same time. But because the uniform classification would take considerable time to prepare, the Commission ordered an interim adjustment whereby Official class rates were to be raised ro per cent and Southern and Western class rates decreased by Io per cent. These orders were also upheld by the Supreme Court.

There was ample evidence that the rates charged by the Southern railroads were not justified by transportation criteria, especially costs of providing the service. Had the Commission chosen to lower Southern rates to the level of existing Official rates, the findings would undoubtedly have been upheld as being supported by evidence. But there was in the original report of the Com-

${ }^{23}$ See the letter from Prof. Edward H. Chamberlain, N.Y. Times, p. I4, col. 6 (May 26, I945).

24 Interstate Commerce Act $\S$ I5 (x), 24 Stat. 384 ( 1887 ), as amended, 49 U.S.C.A. $\$ 15$ (Supp., I946).

${ }^{25}$ The Commission found that differences in the rate levels were not justified by cost of service, consists of traffic, distribution of the rate burden, or other factors usually considered. Class Rate Investigation, I939, 262 I.C.C. $447,694,696$ (I945). It is noteworthy, however, that there are no explicit findings as to whether or not the existing rates were justified on value of service considerations.

${ }^{26} \mathrm{Mr}$. Justice Douglas was undoubtedly troubled in attempting to reconcile the Commission's findings that the discrepancies between Offcial and Western rates were not justified by differences in the costs of service with its findings that costs of service in Western Territory were as much as ro per cent greater than costs in Official Territory. The Court was, however, fully prepared to trust the trained judgment of the Commissioners on so delicate a problem. New York v. United States, 67 S. Ct. I207, 1232 (1947). 
mission no explicit finding that Official class rates were unreasonably low, ${ }^{27}$ and there was absolutely no evidence explicitly pointing to this conclusion. ${ }^{28}$ Unfortunately, the language of the Supreme Court in passing on this phase of the Commission's action is not unequivocal. It may be that the Court believed the Commission did actually find the Official rates were too low, and was reluctant to upset the finding. If this is so, it represents an amazing deference to the administrative process, because of the paucity of supporting evidence. ${ }^{29}$ However, there are broad statements both in the Commission's report and the Court's decision which seem to imply that such a finding is not necessary - that when undue discrimination is found the Commission is empowered to remove it by setting maximum and minimum rates, without inquiring into the measure in which the discrimination has been caused by each rate.

There had been no prior decision of the Commission or Court in which the propriety of such action has been tested. The reason may be found in the long prevalence of the doctrine of the Ashland case, ${ }^{30}$ which held that unlawful preference or prejudice necessarily involves the responsible participation by the same carrier in both the preferential and prejudicial rate in the sense of being able to end the discrimination by its own action. It was hoped that this rule merely reflected the legal inability of the Commission to cope with such discrimination before it acquired the minimum rate power, ${ }^{3 \mathrm{x}}$ but even after ${ }^{2} \mathbf{2}^{2} \mathrm{O}$ the Commission and the Supreme Court maintained that the definition of dis-

${ }^{27}$ In the Commission's report, on reconsideration of the case, it expressed surprise that anyone should fail to see such an explicit finding in its original report, and to satisfy everyone concerned it went on record as making such a finding. Class Rate Investigation, I939, 264 I.C.C. $4 \mathrm{r}, 62$ (I945). The order increasing Official rates must have been a surprise to all the parties involved. All discussion of the interterritorial freight rate problem had been in terms of the excessive Southern and Western rates. No one suggested that the Official rates were too low, and the only writer who discussed the possibility of removing the discrimination by raising Official rates rejected the idea as uneconomic and unduly burdensome. Kline, Freight Rates, The Interregional Tariff Issue 27 (1942). In the hearings before the Commission not a single party, with the exception of the motor carriers, who had their own axe to grind, favored an increase in Official rates. Dissent of Commissioner Porter, Class Rate Investigation, I939, 262 I.C.C. 447,718 (1945).

${ }^{28}$ See Commissioner Patterson's partial concurrence, Class Rate Investigation, I939, 262 I.C.C. 447, 708 (1945); and Commissioner Porter's dissent, ibid., at 719. The only evidence even implicitly supporting such a conclusion is the fact that recently the rate of return has tended to be higher for Southern and Western than for Official railroads, but this is not conclusive, and no findings were based on these facts.

${ }^{29}$ Comparison with Interstate Commerce Commission v. Mechling, 67 S. Ct. 894 (r947), decided a few weeks earlier, is illuminating. There the Court went behind the Commission's cost findings and rejected them because of "unsifted averages." It refused to uphold an increase in the reshipping rates on ex-barge grain because there was no showing as to how much of the increase was necessitated by higher costs. Professor Currie distinguishes standards in such decisions as this as having been applied in "less momentous" cases, Foreword, I 2 Law \& Contemp. Prob. 39r, 399 (1947).

${ }^{30}$ Ashland Fire Brick Co. v. Southern R.R. Co., 22 I.C.C. Ix 5 (IgII); Texas \& Pacific R. Co. v. United States, 289 U.S. 627,650 (I933).

${ }^{3 \pi}{ }_{3}$ B Sharfman, op. cit. supra note Io, at $63^{6}-4$ I. 
crimination involved effective participation by the same carrier in both rates. ${ }^{32}$ The consequences of this rule were serious in that many types of undesirable discriminations flourished because of this artificial distinction. The rule was adhered to largely because it was a means of safeguarding against the Commission's consideration of commercial and economic conditions as factors in the determination of proper rate levels. ${ }^{33} \mathrm{An}$ order for the removal of discrimination was always directed against a carrier who was responsible for both rates in the sense of being able to remove discrimination by its own action. In most cases the order was under Section $3(\mathrm{I})$ and the carrier was given the option of removing the discrimination by any rate adjustment which it saw fit. But even where the order was under Section I 5 (I) the problem as to the interpretation of "maximum and minimum" could never be fully explored because the Commission's orders were likely to be based upon the removal of the particular discriminating factor, and a minimum rate order would not issue unless the rate in question were unreasonably low. And where a minimum rate order was issued and the shipper complained, the situation could always be rationalized by saying that after all he had had the benefit of a subsidy all this time because of the improper distribution of his carrier's rate burden, and the subsidy was now being removed.

In Nevo York v. United States ${ }^{34}$ the Supreme Court effectively assigns the Ashland rule to limbo. It said that the rule applied only where the Commission ordered the carrier to remove the discriminations itself and does not apply to Section 15 orders. ${ }^{35}$ This holding is based on a dictum in Central R.R. Co.v. United States ${ }^{36}$ that the Commission may require carriers to establish reasonable rules and regulations even though the same carrier is not responsible for both routes on which the discriminatory practice was exercised. It is submitted that this analogy is greatly strained. Substantial differences exist between the fixing of rates and the granting of "creosoting-in-transit" privileges, and the wisdom

${ }^{2}$ Mansfield, The Minimum Rate Power and the Control of Competition, 45 Yale L. J. I406. $\mathrm{r}_{4} \mathrm{I}_{2}$ (1936). The only modifications in the rule have been in the direction of finding discrimination where two carriers or more were concerned, but where one effectively controlled the rates to both affected regions. 3 B Sharfman, op. cit. supra note io, at 64 I. See Central R. Co. v. United States, 257 U.S. 247, 259-60 (z92I); Texas \& Pacific R.R. Co. v. United States, 289 U.S. 627,650 (I933).

${ }^{33}$ Ashland Fire Brick Co. v. Southern R.R. Co., 22 I.C.C. II5, I2I (IgII). But see $3 B$ Sharfman, op. cit. supra note ro, at $64 \mathrm{r}, \mathrm{n} .5^{69}$.

3467 S. Ct. 1207 (1947).

35 Tbid., at 1238 . This seems to beg the question because before an order may be issued under Section $r_{5}$ it must be shown that the rates are unlawful. New Automobiles in Interstate Commerce, 263 I.C.C. 771,779 (1945). By definition there can be no discrimination unless a carrier controls both rates. Although an alternative order was not required in removal of discrimination, Youngstown Sheet and Tube Co. v. United States, 295 U.S. 476, 480 (I935), the possibility of the carrier's effective removal of the discrimination in alternative manners apparently remained a test of discrimination. Automobiles to Southern Ports for Export, 2I6 I.C.C. II3, I 23 (1936); Sheboygan v. Chicago \& Northwestern R.R. Co., 227 I.C.C. 472, 476 (I938).

${ }^{36} 257$ U.S. 247,257 (I92I). 
of the analogy is open to serious question. Despite the fact that the demise of the Ashland rule makes possible more effective handling of the discrimination problem, it gives rise to the more troublesome problem of the manner of removal of the discrimination found. Where the same carrier does not serve both regions, standards of comparison are lacking, and the possibility exists that a minimum or maximum rate order will be entered against a carrier whose rate burden has been ideally distributed instead of against the carrier whose rate policies are really the basis for the discrimination. For the first time the question arises as to whether a shipper who is paying rates which are fully compensatory to the carrier, and which have not been unreasonably low by any standards except the inability of other shippers to compete, should be required to pay increased charges to remove an alleged discrimination. In view of the fact that the regulation of the railroads was instituted primarily to protect the shippers and the consuming public from the extortions of monopolistrc excesses, ${ }^{37}$ and to guarantee to the public benefits in the form of national unity, territorial specialization, lower prices, and greater diversity of available products flowing from low transportation $\operatorname{costs},{ }^{38}$ the crucial query becomes: Under what circumstances is it in the public interest that the shipper be ordered by the regulatory body to pay higher rates?

The minimum rate power was granted to the Commission as a weapon with which to fight discrimination and maintain balance in the transportation structure. ${ }^{39}$ But it has always been realized that the exercise of the power is anomalous in that its improper use might tend todeprive shippers and the public of the benefits of legitimate price competition..$^{\circ}$ Therefore, despite the oft-repeated statement that the criteria for determining the propriety of a minimum rate order are the same as those for the maximum rate power, ${ }^{47}$ the Commission has been most reluctant to exercise the minimum rate power..$^{22}$ Its use seems to have been limited in actual practice to situations where an undue discrimination is caused by an unreasonably low rate, 43 or to situations in which the rate is not really too low, but must be raised in order to prevent serious disruption of the transportation system and the rate structure. 44

37 I Sharfman, op. cit. supra note ro, at I3-rg. $\quad 3^{8}$ Bigham, op. cit. supra note 9 , at $3-\mathrm{II}$. ${ }^{39}$ Mansfield, op. cit. supra note 32 ; Bikle, The Power of the Interstate Commerce Commission To Prescribe Minimum Rates, 36 Harv. L. Rev. 5 (Ig22).

${ }^{40}$ See Commissioner Eastman's testimony in Hearings before the House Committee on Interstate and Foreign Commerce on the Omnibus Transportation Bill, 76th Cong. Ist Sess., at I710 (1939); Sugar Cases of r922, 8I I.C.C. 448,472 (I923).

${ }^{42}$ Salt Cases of 1923,92 I.C.C. 388 ( 1924$)$.

43 H. Moffat Co. v. Southern Pacific Co., I95 I.C.C. I98, 200 (1933); Cloverdale Spring Co. v. Atlantic Coast Line R.R. Co., I74 I.C.C. I33, I38 (I93I); Iron and Steel Articles, I55 I.C.C. $5 \times 7$ (1929); Sugar Cases of I922, 8I I.C.C. 488 (I923).

${ }^{43}$ An unreasonably low rate, in this context, may be defined as one which may be reasonable per se, but nevertheless not reasonably compensatory. See Witters, A Study of Minimum Reasonable Rates, I3 I.C.C. Pract. J. 438 (I946).

44 Youngstown Sheet \& Tube Co.v. United States, 295 U.S. 476 (I935); Scandrett v. United States, 32 F. Supp. 995 (Ore., I940); Sugar from New Orleans to Arkansas, 243 I.C.C. 703 
To the extent that the Supreme Court has sanctioned the use of a minimum rate order to remove a discrimination without a showing that the existing rate is unreasonably low, rate regulation has entered upon a new phase of its existence, the limits of which cannot be ascertained.45 It not only gives the Commission free reign to issue an anti-discrimination order which has no quantitative relationship to the amount of discrimination found to exist, but it also enables the Commission to tamper with critical adjustments of the national economy, at its discretion, in the eradication of actual or imagined discriminations. ${ }^{6}$ Moreover, it gives the Commission another device with which to protect vested interests from technological advance and economic progress. 47 And not the least of the consequences of the decision is the recognition of the Commission's power arbitrarily to replace ideals of low cost transportation and consumer goods at prices competitively determined with rate rigidities based only on uncontrolled discretion.

(194I); Coal from Indiana to Illinois, I97 I.C.C. 245 (1933). See also Freight, All Kinds, between Lincoln, Omaha, and Nebraska Points, 32 M.C.C. 339, 344 (I942); Sugar Cases of I922, 8I I.C.C. 448,472 (1923). In these cases the Commission refused to issue minimum rate orders where existing rates were compensatory and there was no threat of a rate war or disruption of the rate structure, even though discrimination was alleged.

45 It may be argued that since discrimination is only a matter of a rate relation, it may be removed by merely adjusting the relationship between the rates without regard to the actual rate figure. In the long run the same results will ensue as between the shippers directly involved in the rate adjustment, but in the short run the impact on the shippers whose rates are raised will be much more severe. In the Class Rate case, the Official shippers who used class rates were confronted with rate increases which they must immediately absorb in their profit margins, but this may be difficult to do well because production plans and commitments have probably been projected well into the future. Furthermore, since only shippers on class rates have had their costs increased, they are at a competitive disadvantage as against shippers who are on commodity or exception rates, in vying for the consumer dollar. Moreover, if the object is to promote the desired policy with a mininum of disruption, raising Official rates is a much poorer technique than lowering Southern and Western rates because the former method confronts the Official shippers with the necessity for immediate adjustment, while the latter will give him several years' grace until the necessary industrial facilities are made available and a labor force trained.

${ }^{6}$ If the contentions of the Southern bloc are valid, the final decision in this case should set in motion powerful forces leading to the reallocation of industrial resources throughout the nation, and such a reallocation will necessarily involve considerable economic distress in many areas of the nation. We have no assurance that these disruptions will be justified by the actual appearance of the anticipated economic blessings. Many questions are left unanswered by the Commission and the Court as to whether or not the prescribed rate structure will move the freight, and whether the necessitated readjustments in the distribution of the rate burden will be reasonable. But one cannot be certain that the whole affair is more than a gesture. There is no reason why the railroads cannot reclassify commodities or remove them from the class rates altogether, and it appears that this is precisely what the Official Territory railroads have done. N. Y. Times, p. 29, col. 6 (June 20, 1945).

47 "The power to fix minimum prices is the power to protect a vested interest against the consequences of competition, justified in a dynamic society only by a greater public advantage in stability than change." Mansfield, op. cit. supra note 32, at 1406. See also Wiprud, op. cit. supra note 5 , at 14,44 . 
In its origin the regulatory process was designed only to regulate the basic relationship between shipper and carrier to insure lower transportation costs and resultant lower commodity costs. The public interest was equated with the shipper's interest, and the latter could be relied on to press for lower rates. The Transportation Act of $192 \mathrm{O}^{8}$ marked a break with this concept of regulation, and for the first time a clearly formulated national policy appeared.49 The Commission was commanded to assume a "fostering guardianship" 50 over the railroads, and it was to consider the adequacy and well-being of the transportation structure of the nation, as well as the relationship between shipper and carrier. The concept of positive control expanded necessarily at the expense of the concept of economy of transportation charges. The ultimate step in the process was the Class Rate litigation, which involved a complete subversion of notions of minimum cost transportation to those of equalization of industrial opportunity, and the decisions have completely lost sight of the basic relationship between shipper and carrier, and the basic goal of low cost transportation.

Rate regulation of the railroads was instituted because of the obvious failure of the monopolistic railroad system to establish a just system of rates within the framework of a free enterprise structure. Although increasing political sophistication has largely dispelled the notions that regulation through administrative bodies is an instrument of political tyranny, the Class Rate litigation has emphasized other serious dangers inherent in the regulatory process. It has not been widely recognized that rate regulation, no less than monopolistic rate determination, is fundamentally inconsistent with notions of a "democratic economy," and may create conditions which weaken the efficacy of the entire competitive pricing process to the point of destroying it. In "the good society" the ideal rate structure would be one in which rates equalled the costs of producing the service..$^{5 x}$ The regulatory process is as incapable of achieving this ideal as the pre-regulatory monopoly was. The Commission does not even attempt to make rates on a cost of service basis, but rather utilizes a number of vague concepts (including cost, value of service, risk, etc.) and emerges with a rate based on a rough sense of justice and expediency, and not at all on sound economic principles. Because of the cumbersome, time-consuming litigation required to change a rate, rigidities are created in the price structure, and these cannot be removed in times of price fluctuations in order to facilitate the reallocation of resources essential to restore stability. ${ }^{52}$ Nevertheless, the expedient of rate regulation has been accepted by everyone as preferable to monopolistic rate determination. But as the regulatory process passes beyond the stage of merely measuring standards such as cost of production against rates and determining their rela-

${ }_{48}^{8}$ r Stat. 456 (1920).

49 I Sharfman, op. cit. supra note Io, at r77-82.

so Dayton-Goose Creek R. Co. v. United States, 263 U.S. 456, 478 (rg24).

${ }^{5 x}$ Bigham, op. cit. supra note. 7 , at 219-20.

s2 Simons, A Positive Program for Laissez Faire Io, II, I4 (I934). 
tion, ${ }^{53}$ regulation becomes wholly inconsistent with the larger competitive system. Whatever semblance of consistency there ever was between a competitive economy and railroad rate regulation has been completely wiped out by the acceptance of the new notions as to the nature of discrimination and the manner of its removal, particularly in the approval of the completely arbitrary use of the minimum rate power. As the area of administrative discretion expands beyond this relatively objective operation of weighing rates against objective standards, the possibilities of anomalous economic rigidities increase, and as discretion displaces established rules the regulatory bodies become centers of economic power, politically applied. While much talk about administrative agencies being inconsistent with the "rule of law" is to be discounted as the reflections of those who have profited at the public expense by non-regulation, it must be conceded that such a concentration of discretionary powers in the hands of administrative commissions, particularly in the field of railroad rate-making, raises serious questions as to the proper location of this type of economic and political power in a democratic society. 54 As the necessity for Commission action according to established criteria decreases and the power to act without first establishing and defining the grounds of action according to accepted standards increases, the regulatory process becomes increasingly susceptible to political pressure and the dominance of special interests.55 Whether these dangers of economic rigidities and political rather than competitive determination of prices are the necessary price of protection of the public interest remains to be determined. There are those who believe that regulation has outlived its usefulness and that competition free from regulation can and will remove the discriminations supposedly inherent in the railroad rate structure, ${ }^{56}$ and that a form of this competition is now a possibility in view of the development of motor carrier and air transport services. ${ }^{57}$ On the other hand, the possibility of nationalizing the railroad system, writing off the fixed costs of the system as social cost, and basing rate charges on cost of service must be considered..$^{8}$

Whatever the possibile solution may be, the problems are now sharply defined. If this type of minimum rate power is essential to the removal of discriminations, as the Supreme Court says, ${ }^{59}$ how will its exercise fit in with other dominant concepts of our economic and political institutional framework?

${ }^{53} 3$ B Sharfman, op. cit. supra note ro, at 763 .

54 Simons, op. cit. supra note 52.

55 I Sharfman, op. cit. supra note Io, at 227-35.

${ }^{6}$ Locklin, op. cit. supra note 7 , at $150-53$.

57 Ibid.; Wiprud, op. cit. supra note 5 .

${ }^{8}$ The concept of marginal cost is the most efficient regulator of the allocation of resources, but it cannot be effectively used in the field of railway rates because of the inherent difficulties caused by the large fixed costs. Under a system of government ownership the public would pay the fixed costs, and the rates could be constructed on the marginal cost principle. See Pigou, Economics of Welfare (r924); Wilson and Rose, Out of Pocket Cost in Railroad Freight Rates, 60 Q. J. Econ. 546 (I946).

59 New York v. United States, 67 S. Ct. 1207, I240 (I947). 
Even assuming that the accretion of political power in the independent administrative agencies can be curbed short of the oft-predicted dictatorial disaster, what are the implications for the competitively determined price system of the nation? And not the least of the problems raised is whether the regulatory process can continue in a partisan political climate when it has once been given the apparent power to equalize economic opportunity, ${ }^{60}$ albeit in terms of the older notions of application of transportation standards.

\section{TORT LIABIIITY FOR MISCARRIAGE "CAUSED" BY FRIGHT}

The field of emotional disturbance has long been a troubled area in the law. Untouched but physically injured plaintiffs have fought a fifty-year battle for redress. They have been blocked mainly by the court's inability to find a causal connection between the negligent act causing their fright and the subsequent physical injury. One class of plaintiffs, however, has had widespread success in the courts. "With few exceptions," Dean Green has said of "fright" cases, "recoveries have been restricted to women, and for the most part pregnant women." I

The early English cases adopted the view that physical harm resulting from the shock caused by another's tortious act was too remote to justify the award of damages. ${ }^{2}$ That the English courts were aware of the weakness of this position is indicated by the slow destruction of the original rule in cases of injury caused by fear for one's own safety, ${ }^{3}$ for the safety of one's husband or children, 4 for passengers, ${ }^{5}$ and, possibly, even for strangers on the highway. ${ }^{6}$

60 The Commission reached its lowest point of respectability and political independence when it departed from the relatively objective transportation standards in favor of the politicoeconomic standards provided by the Hoch-Smith Resolution. Mansfield, op. cit. supra note I 5 , at 165-83; 2 Sharfman, op. cit. supra note Io, at 452-89; Robinson, The Hoch-Smith Resolution and the Future of the Interstate Commerce Commission, 42 Harv. L. Rev. 6ro (I929). Nevertheless, some rejoice in the precedent established in the Class Rate case because the Commission has once more been opened to political pressure. Britt, Tracks to a New Frontier, 36 Survey Graphic 394 (I947).

× Green, "Fright" Cases, 27 Ill. L. Rev. 76I (I933).

2 Victorian Ry. Comm. v. Couitas, 13 A.C. 222 (1888).

3 Dulieu v. White, [rgor] 2 K.B. 669.

4 Hambrook v. Stokes, [x925] I K.B. I4I (mother's fear for her children); Brandon v. Garrett \& Co., Ltd., [1924] I K.B. 548 (fear for husband); Wilkinson v. Downton, [I897] 2 Q.B. 57 (fear for husband).

5 Pugh v. London, Brighton and South Coast Ry., [I896] 2 Q.B. 248 (nervous shock due to signalman's fear for safety of passengers held within the purview of "accident" in an insurance policy).

${ }^{6}$ See Hambrook v. Stokes, [1925] ₹ K.B. I4T, where Atkins, I.J., expressed the opinion that a mere bystander on the highway could obtain damages for shock arising from apprehension or actual sight of injury to a third party. 